\title{
Negocjowanie układów zbiorowych pracy
}

\section{Pojęcie negocjacji układowych}

R okowania zbiorowe w stosunkach pracy są jednym z najważniejszych Rinstrumentów kształtowania nowoczesnego ustroju pracy. Ich ranga znajduje odzwierciedlenie przede wszystkim w art. 59 ust. 2 Konstytucji RP, w myśl którego związki zawodowe oraz pracodawcy i ich organizacje mają prawo do rokowań w szczególności w celu rozwiązywania sporów zbiorowych oraz do zawierania układów zbiorowych pracy i innych porozumień. Kompetencja do układowych negocjacji zbiorowych została przewidziana także w dokumentach międzynarodowych, m.in. w konwencjach Międzynarodowej Organizacji Pracy. Prawo do rokowań gwarantuje art. 4 ratyfikowanej przez Polskę Konwencji nr 98 z 1 lipca 1949 r., dotyczącej stosowania zasad prawa organizowania się i rokowań zbiorowych ${ }^{1}$ oraz art. 2 Konwencji nr 154 z 3 czerwca 1981 r., odnoszącej się do popierania rokowań zbiorowych. Kompetencja ta jest zagwarantowana także w ratyfikowanej przez Polskę Europejskiej Karcie Społecznej z 18 października 1961 r. ${ }^{2}$

Artykuł $241^{2} \S 1$ k.p. stanowi, że układ zbiorowy pracy zawierany jest $\mathrm{w}$ drodze rokowań. W tytule niniejszego opracowania posłużyłem się terminem negocjowanie - od pojęcia negocjacje. Traktuję go jako synonim kodeksowego pojęcia rokowania ${ }^{3}$. Odwołałem się do pojęcia negocjacje/negocjowanie, gdyż w tekście koncentruję się na kwestiach proceduralnych $i$, jak mi się wydaje, to on lepiej i bardziej syntetycznie je uwypukla niż termin rokowania czy pochodny od niego zwrot prowadzenie rokowań.

* Dr hab. prof. nadzw., dziekan Wydziału Prawa i Administracji Uniwersytetu Warszawskiego.

1 DzU, 1958, nr 29, poz. 126.

${ }^{2}$ DzU, 1999, nr 8, poz. 67 ze zm.

3 Tak Stownik poprawnej polszczyzny, Warszawa 1995, s. 389. 
Zgodnie z art. 2 Konwencji nr 154, odnoszącej się do popierania rokowań zbiorowych, rokowania takie dotyczą wszystkich negocjacji, które następują między pracodawca, grupą pracodawców albo co najmniej jedną organizacją pracodawców z jednej strony i co najmniej jedną organizacją pracowników z drugiej, w celu:

- określenia warunków pracy i zatrudnienia; i/lub

- uregulowania stosunków miedzy pracodawcami a pracownikami; i/lub

- uregulowania stosunków między pracodawcami bądź ich organizacjami a organizacją lub organizacjami pracowników.

Jeżeli zważymy zakres przedmiotowy układu zbiorowego pracy określony w art. $240 \S 1$ k.p., to skonstatujemy, że powyższe określenie rokowań/negocjacji zbiorowych wprost odnosi się do rokowań/negocjacji układowych. Istota negocjacji zbiorowych polega na tym, że ich uczestnicy - partnerzy socjalni wspólnie rozpatrują interesujące ich zagadnienia $\mathrm{w}$ celu uzgodnienia stanowiska $\mathrm{w}$ ich przedmiocie. W przypadku układu zbiorowego pracy - w celu określenia w nim warunków, jakim powinna odpowiadać treść stosunku pracy oraz wzajemnych zobowiązań jego stron. Zawarcie układu zbiorowego pracy wymaga więc zgodnego oświadczenia woli jego stron.

Negocjacje zbiorowe, w tym układowe, odróżnić należy od uzgadniania 494 regulaminu pracy czy wynagradzania. W ramach rokowań strony wspólnie określają ich pole, ich zakres przedmiotowy. Proces uzgadniania regulaminu pracy czy regulaminu wynagradzania porównać można do oferty jako sposobu zawarcia umowy cywilnoprawnej. To na pracodawcy ciąży obowiązek przedstawienia związkom zawodowym projektu stosownego regulaminu, a związki mogą go zaakceptować bądź odrzucić. Na tle rozróżnienia negocjacji zbiorowych ze związkami zawodowymi od procesu uzgadniania z nimi regulaminów powstała kwestia, czy dopuszczalne jest zawarcie układu zbiorowego pracy w sytuacji, gdy jedna ze stron przedstawiła projekt układu, a druga go zaakceptowała, czyli gdy z formalnego punktu widzenia nastąpił proces uzgodnienia układu, a nie jego wynegocjowania.

W piśmiennictwie prezentowany jest pogląd, że dopuszczalne jest zawarcie układu zbiorowego pracy, ,jeżeli jedna ze stron zaproponuje zawarcie układu określonej treści, a druga to zaaprobuje..." Zdaniem autora tego poglądu, skoro strony, stosownie do art. $241^{10}$ k.p., mogą zawrzeć porozumienie o stosowaniu „obcego" układu, którego nie negocjowały, to tym bardziej mogą bez negocjacji zawrzeć własny układ zbiorowy pracy. Kwestia ta, zdaniem autora, nie ma większego znaczenia praktycznego, ponieważ przy zawieraniu układu zbiorowego pracy z reguły mamy do czynienia z negocjacjami ${ }^{4}$. Zgadzając się co do zasady z L. Florkiem

\footnotetext{
${ }^{4}$ Por. L. Florek, Kodeks pracy. Komentarz, Warszawa 2011, s. 1120.
} 
wskazać należy, że ustawowy zwrot o zawarciu układu „w drodze rokowań" należy rozumieć w ten sposób, iż w procesie dochodzenia do ustanowienia porozumienia zbiorowego muszą być spełnione wymagania proceduralne przewidziane $\mathrm{w}$ przepisach działu jedenastego Kodeksu pracy. Nawet jeżeli propozycja regulacji układowej zgłoszona przez jedną stronę miałaby być przyjęta przez drugą stronę, to powinna zostać ona skierowana do wszystkich organizacji związkowych reprezentujących pracowników, dla których ma być zawarty układ ${ }^{5}$; nie powinno też dojść $\mathrm{w}$ ten sposób do naruszenia interesów pracowników nieobjętych ukła$\mathrm{dem}^{6}$. Akcentowanie procedury rokowań przy zawieraniu układu zbiorowego pracy ma jednak swój wymiar praktyczny, ponieważ zapobiega ona sytuacjom, w których odmowa przyjęcia oferty układu zgłoszonej przez jedną ze stron może być potraktowana przez drugą stronę jako odmowa zawarcia tego porozumienia zbiorowego. W razie takiej odmowy strony winny przystąpić do normalnych negocjacji na bazie propozycji składanych przez każdą z nich.

Z art. $241^{3} \S 1$, art. $241^{16} \S 1$ i 2 oraz art. $241^{25} \S 1$ i 2 k.p. wynika, że strony rokowań układowych powinny wyrażać chęć zawarcia układu zbiorowego pracy, a negocjacje te są procesem, w ramach którego ich uczestnicy oddziałują na siebie wzajemnie, spotykają się, przedstawiają swoje stanowiska i dyskutują o propozycjach dotyczących przyszłego układu. Ponieważ w negocjacjach układowych biorą udział partnerzy socjalni, związkowe przedstawicielstwo pracowników oraz pracodawca lub jego reprezentacja, powiązani interesami, z których istotna część nie pokrywa się, a niektóre są ze sobą sprzeczne, rokowania układowe należy ujmować także jako sposób osiągania kompromisu, uzgadniania owych niespójnych interesów. Negocjacje takie cechuje więc stopniowe uzgadnianie stanowisk ich uczestników, a działań tych nie da się ściśle rozdzielić ze względu na ich znaczenie dla przebiegu całości procesu zmierzającego do opracowania układu zbiorowego pracy. $W$ ramach negocjacji uczestniczące $w$ nich reprezentacje strony pracodawczej i związkowej powinny przedstawić sobie wzajemne propozycje co do treści przyszłego układu, określające pole rokowań. Za wątpliwą należy uznać praktykę, gdy pracodawca przedstawia projekt układu, który następnie jest przedmiotem dyskusji ze związkami zawodowymi. Procedura taka bowiem, jak już wyżej wskazano, właściwa jest dla procesu uzgadniania ze związkami zawodowymi np. regulaminu pracy czy też regulaminu wynagradzania, a nie dla rokowań, w ramach których dochodzi do przedstawienia i konfrontacji stanowisk ich uczestników, a następnie do wypracowania swego rodzaju kompromisu.

\footnotetext{
${ }^{5}$ Por. art. $241^{2} \S 2$ k.p.

${ }^{6}$ Por. art. $241^{3} \S 1$ pkt 3 k.p.
} 


\section{Inicjatywa podjęcia negocjacji układowych}

Z inicjatywą podjęcia negocjacji nad zawarciem lub zmianą układu zbiorowego pracy może wystąpić zarówno strona związkowa, jak i strona pracodawcza, choć częściej robi to ta pierwsza. O inicjatywie podjęcia rokowań układowych powinny być powiadomione wszystkie związki zawodowe reprezentujące pracowników, dla których ma być zawarty układ zbiorowy. Obowiązek takiego powiadomienia spoczywa na podmiocie występującym z inicjatywą negocjacji. Dotyczy on zarówno strony pracodawczej, jak i związkowej. Jeżeli z inicjatywą podjęcia rokowań wychodzi jeden ze związków reprezentujących pracowników, to adresując ją do strony pracodawczej, winien on niezwłocznie poinformować o tym pozostałe organizacje związkowe. Artykuł $241^{2} \S 2$ k.p., stanowiący o omawianym obowiązku, nie przewiduje żadnej szczególnej formy jego realizacji, a więc powiadomienie może nastąpić zarówno w formie pisemnej, elektronicznej, jak i ustnej. Ze względów porządkowych jednak bardziej pożądana jest forma pisemna/elektroniczna. Wskazany artykuł nie ustala także expressis verbis żadnego terminu powiadomienia organizacji związkowych. Ponieważ jednak stanowi on łącznie o wystąpieniu z inicjatywą podjęcia rokowań i o powiadomieniu związków zawodowych, to można uznać, że intencją ustawodawcy było dokonanie tych czynności w tym samym czasie. Nie zawsze jednak będzie to możliwe, szczególnie w przypadku zamiaru zawarcia układu ponadzakładowego, gdy brak jest pełnego rozeznania co do organizacji związkowych reprezentujących pracowników, dla których układ ma być zawarty. W takiej sytuacji powiadomienie poszczególnych związków zawodowych może nastąpić $\mathrm{w}$ różnym czasie. $W$ każdym razie powiadomienie wszystkich związków reprezentujących pracowników jest warunkiem prawidłowego podjęcia negocjacji układowych. Podjęcie rokowań z naruszeniem omawianego obowiązku powoduje ich wadliwość i niemożność skutecznego zawarcia układu. Gdyby mimo to doszło do podpisania takiego układu, to zarzut pominięcia podmiotu uprawnionego do negocjowania układu może być zgłoszony w postępowaniu rejestrowym, o którym stanowi art. $241^{11} \mathrm{k}$.p. albo organ rejestrujący sam ustali omawianą tu wadę i odmówi rejestracji zgłoszonego układu. Stosownie do $§ 2$ powołanego artykułu rejestracji podlega układ zawarty zgodnie z prawem. Oznacza to, że organ rejestrujący bada nie tylko zgodność z prawem treści postanowień tego porozumienia zbiorowego, lecz także to, czy jego strony zostały prawidłowo wyłonione, w szczególności, czy do negocjacji zostały dopuszczone i czy w niej uczestniczyły wszystkie uprawnione podmioty. 


\section{Dobrowolność negocjacji układowych}

Układ zbiorowy pracy jest porozumieniem zawieranym przez autonomiczne względem siebie podmioty prawa, dlatego też ustawodawca ustanowił $\mathrm{w}$ art. $241^{2} \S 3$ k.p. zasadę, że wszczęcie negocjacji $\mathrm{w}$ celu zawarcia układu zależy jedynie od woli stron upoważnionych do jego zawarcia. Jednocześnie przepis ten statuuje wyjątki od reguły, w których strona będąca adresatem inicjatywy podjęcia rokowań jest obowiązana je podjąć. Bliższa analiza sytuacji, w których podjęcie negocjacji w celu zawarcia układu jest obligatoryjne, czyni zasadę swobody rokowań wysoce względną.

Przede wszystkim należy stwierdzić, że każda pierwsza inicjatywa podjęcia negocjacji nad zawarciem nowego układu zbiorowego pracy, zgłoszona po dniu wejścia w życie ustawy z 29 września 1994 r. nowelizującej dział jedenasty Kodeksu pracy, tj. po 29 listopada 1994 r., stwarza po stronie adresata inicjatywy obowiązek podjęcia rokowań. Wniosek taki jasno wypływa z analizy porównawczej art. $241^{2} \S 3$ pkt 1 k.p. z art. 12 powołanej ustawy nowelizującej. Pierwszy ze wskazanych przepisów stanowi, że obligatoryjne są rokowania „w celu zawarcia układu dla pracowników nieobjętych układem”, drugi zaś przewiduje, że przez pojęcie układu, o którym była mowa, należy rozumieć układ zawarty po dniu wejścia w życie ustawy nowelizującej, obowiązkowe są więc negocjacje w celu zawarcia nowego układu po 29 listopada $1994 \mathrm{r}$.

Kolejną przesłanką obligatoryjności negocjacji układowych, określoną $\mathrm{w}$ art. $241^{2} \S 3$ pkt 2 , jest istotna zmiana sytuacji ekonomicznej bądź finansowej pracodawców lub pogorszenie się sytuacji materialnej pracowników. Należy stwierdzić, że przesłanki te zostały określone w sposób ogólny, zastosowano nieostre zwroty - „istotna zmiana” oraz „pogorszenie się sytuacji". W Kodeksie pracy nie zostało ustalone ani to, kto dokonuje ocen w tym zakresie, ani jakie są kryteria dokonywania tych ocen. Jeżeli przyjąć, że oceny aktualności owych przesłanek dokonuje w sposób autonomiczny każdy podmiot uprawniony do wystąpienia z inicjatywą zawarcia układu zbiorowego pracy, to należy uznać, że ustawodawca dopuścił subiektywizację tych ocen. Okoliczność ta może być czynnikiem konfliktogennym, ponieważ umożliwia odmienność ocen w sprawie tak istotnej, jak konieczność podjęcia rokowań układowych. Sytuacji powstawania sporów na tle istnienia obowiązku rozpoczęcia negocjacji układowych może zapobiec określenie w układzie, który miałby podlegać nowelizacji na podstawie wymienionych przesłanek, trybu i warunków ustalania, czy istotnej zmianie uległa sytuacja ekonomiczna bądź finansowa pracodawców oraz czy pogorszeniu uległa sytuacja materialna pracowników. Należy jednak pamiętać, że ustalenie w układzie zbiorowym 
systemu dokonywania takich ocen zależy od woli jego stron ${ }^{7}$. W wyroku z 5 czerwca 2013 r. Sąd Apelacyjny w Gdańsku (III AUa 1246/2012, LexPolonica nr 7226764) stwierdził, że art. $241^{2} \S 3$ k.p. regulujący zakaz odmowy rokowań w celu zawarcia układu zbiorowego pracy, łącznie $\mathrm{z}$ istotną zmianą sytuacji ekonomicznej lub finansowej, wymienia pogorszenie się sytuacji materialnej pracowników. Obydwa unormowania pozwalają wyciągnąć pewne wnioski co do znaczenia terminu "przyczyny ekonomiczne", na gruncie prawa pracy. Przyczyny ekonomiczne zatem, to takie przyczyny, nieodłącznie związane albo bezpośrednio wynikające z niedoboru środków finansowych, wpływające na podstawową sferę działalności pracodawcy, które w prosty sposób prowadzą do ograniczenia zatrudnienia przy określonym rodzaju pracy poprzez likwidację stanowiska pracy. Radykalniejszym rozwiązaniem byłaby rezygnacja z omawianych tu przesłanek obligatoryjności negocjacji układowych.

Trzecią przesłanką obligatoryjności negocjacji układowych jest upływ 60 dni poprzedzających okres, na jaki układ został zawarty, albo wypowiedzenie układu. Należy w tym miejscu wskazać, że do czasu wydania przez Trybunał Konstytucyjny orzeczenia z 18 listopada 2002 r. $^{8}$ istniała możliwość wykorzystania przesłanki związanej z wypowiedzeniem układu. W orzeczeniu tym Trybunał Konstytucyjny uznał niezgodność art. $241^{7} \S 4$ k.p. z art. 59 ust. 2 Konstytucji RP oraz art. 4 Konwencji nr 98 Międzynarodowej Organizacji Pracy z 1 lipca 1949 r. i art. 6 ust. 2 Europejskiej Karty Społecznej z 18 października 1961 r. Bez większego ryzyka bowiem można było wypowiedzieć układ, skoro i tak, zgodnie z art. $241^{7}$ $\S 4$ k.p., do utraty mocy obowiązującej wypowiedzianego układu było potrzebne albo zawarcie nowego układu, albo zgodne oświadczenie jego stron, ustalające końcowy termin stosowania układu.

W podsumowaniu należy stwierdzić, że choć art. $241 \S 3$ k.p. formalnie statuuje zasadę dobrowolności negocjacji układowych, to jednak zakres i sposób ujęcia sytuacji, w których strona będąca adresatem inicjatywy układowej nie może odmówić żądaniu drugiej strony, powoduja, iż de facto mamy do czynienia z obligatoryjnością negocjacji układowych, zwłaszcza gdy z ich inicjatywą występują związki zawodowe. $\mathrm{O}$ ile bowiem strona pracodawcza nie ma w zasadzie w stosunku do związków zawodowych instrumentu egzekwującego ich powinność podjęcia i prowadzenia rokowań, o tyle te ostatnie mają taką możliwość; jest nią spór zbiorowy z powołaniem się na naruszenie podstawowej, konstytucyjnej kompetencji związkowej - możliwości negocjacji zbiorowych. W litera-

7 Por. K. Rączka w: M. Gersdorf, K. Rączka, M. Raczkowski, Kodeks pracy. Komentarz, Warszawa 2014, s. 1191.

${ }^{8}$ K. 37/01, DzU, 2002, nr 196, poz. 1660. 
turze przedmiotu podaje się to stanowisko $\mathrm{w}$ wątpliwość, stwierdzając po pierwsze, że z obowiązkiem podjęcia rokowań układowych $\mathrm{w}$ sensie prawnym mamy do czynienia wówczas, gdy z niewykonaniem określonej dyspozycji wiążą się gwarantowane przymusem państwowym sankcje, których w omawianych przypadkach nie ma, i po drugie, iż omawiana "sankcja strajkowa" nie wiąże się z obowiązkiem podjęcia negocjacji układowych, związki zawodowe bowiem zawsze mają możliwość wszczęcia sporu zbiorowego w celu skłonienia strony pracodawczej do podjęcia rokowań zbiorowych ${ }^{9}$. Polemizując z przedstawionymi zastrzeżeniami, należy przede wszystkim stwierdzić, że formułując pogląd o obligatoryjności dla strony pracodawczej rokowań układowych wskazano na jej aspekt faktyczny, a nie prawny, użyto bowiem wyrażenia de facto, a nie de iure. Ponadto wskazanie na "uniwersalność" sankcji strajkowej nie tyle podważa prezentowany pogląd, ile raczej go wzmacnia ${ }^{10}$.

\section{Zasady prowadzenia negocjacji}

$\mathrm{W}$ art. $241^{3} \S 1$ k.p. ustanowiono pewne zasady prowadzenia negocjacji układowych, traktując je jako reguły aksjologiczne. Statuując je, ustawodawca uznał, że na obecnym etapie kształtowania zbiorowych stosunków pracy celowa jest ingerencja państwa za pośrednictwem norm prawnych w przebieg rokowań. Należy pamiętać, że w Polsce tradycja kształtowania stosunków pracy w drodze rzeczywistych i odpowiedzialnych negocjacji zbiorowych jest stosunkowo krótka. Zgodnie z powołanym przepisem negocjacje układowe powinny być prowadzone w dobrej wierze i z poszanowaniem słusznych interesów drugiej strony. Na tle tych generalnych wytycznych nasuwa się kilka refleksji. Przede wszystkim wypada stwierdzić, że mamy tu do czynienia z klauzulami generalnymi, których interpretacja i stosowanie napotyka trudności, ponieważ ani w dziale jedenastym Kodeksu pracy, ani w innych przepisach prawa pracy nie znajdujemy zadowalających wskazówek przybliżających ich znaczenie. Przy interpretacji pojęcia "dobra wiara" trzeba nawiązać do ustaleń poczynionych w cywilistyce. W prawie cywilnym dobra/zła wiara odnosi się do czynności prawnych oraz skutków następstwa prawnego ${ }^{11}$. Dobra wiara to przeświadczenie danego podmiotu, że pewne prawo lub stosunek prawny, na który się powołuje, istnieje, chociażby mniemanie to było błędne, jeżeli wynika ono $\mathrm{z}$ usprawiedliwionych przyczyn. Wobec ustanowienia w art. 7 k.c. domniemania dobrej wiary, podstawowe znaczenie dla oceny postępowania

\footnotetext{
9 Por. Z. Hajn, Status prawny organizacji pracodawców, Warszawa 1999, s. 81.

${ }^{10}$ Por. K. Rączka, Kodeks pracy. Komentarz..., s. 1192.

11 Por. w szczególności art. $92 \S 2$, art. $169 \S 1$ i art. $224 \S 1$ i 2 k.c.
} 
danego podmiotu ma nie tyle pojęcie dobrej, ile złej wiary. Przyjmuje się, że w złej wierze działa ten, kto, powołując się na określone prawo lub stosunek prawny, wie, że to prawo bądź stosunek prawny nie istnieje albo też nie wie tego, choć mógł i powinien to wiedzieć. Ustaleń poczynionych w doktrynie prawa cywilnego na temat pojęcia "dobra wiara" nie da się wprost, bezpośrednio przenieść na grunt negocjacji układowych. Ważne jest jednak zwrócenie uwagi na to, że przy ocenie istnienia dobrej wiary należy odwoływać się do subiektywnych zjawisk wewnętrznych, takich jak wiedza, przeświadczenie, przezorność, lojalność. Ponieważ o zjawiskach subiektywnych można mówić tylko w odniesieniu do ludzi, a nie jednostek organizacyjnych, którymi są związki zawodowe, a także organizacje pracodawców i często pracodawcy, dobrą wiarę należy odnosić nie tyle do stron rokowań, ile do osób fizycznych występujących w ich imieniu. Uwzględniając ten fakt, można stwierdzić, że prowadzenie negocjacji w dobrej wierze oznacza rzetelne dążenie osób reprezentujących partnerów socjalnych do pozytywnego efektu prowadzonego dialogu i do zawarcia układu zbiorowego pracy; dążenie to powinno wynikać z przekonania o istnieniu okoliczności i uwarunkowań uzasadniających postulaty zgłaszane w czasie rokowań. Z kolei w złej wierze działa ten, kto - powołując się na pewne okoliczności i uwarunkowania - wie, że one nie istnieją lub nie wie tego, 500 ale brak owej wiedzy nie może $\mathrm{w}$ danych okolicznościach zostać uznany za usprawiedliwiony. Uczestnicy rokowań, przystępując do nich, powinni działać w przekonaniu, że istnieją potrzeba i możliwość osiągnięcia rzetelnego konsensusu. Nie powinni więc traktować negocjacji jako gry pozorów albo formy jednostronnego dyktatu. Prowadzenie negocjacji w dobrej wierze nie oznacza oczywiście rezygnacji z własnych interesów przez każdego z partnerów socjalnych ani nieuzasadnionego ich ograniczania, oznacza natomiast dążenie do osiągnięcia kompromisu. Powyższą konstatację potwierdza druga podstawowa wytyczna prowadzenia negocjacji układowych, a mianowicie poszanowanie słusznych interesów drugiej strony.

W literaturze przedmiotu podano w wątpliwość trafność poglądu, że dobra wiara obejmuje rzetelne dążenie partnerów socjalnych do zawarcia układu zbiorowego pracy wskazując, iż oznaczałoby to wymuszanie możliwości zawarcia tego porozumienia, a tymczasem np. pracodawca może nie być zainteresowany zawarciem $u k ł a d u^{12}$. Trudno jest zgodzić się z tym poglądem. Po pierwsze, dobra wiara jest wytyczną prowadzenia negocjacji układowych, która aktualizuje się na etapie rokowań. Trudno więc mówić o wymuszaniu zawarcia układu zbiorowego pracy, skoro strony już przystąpiły do negocjacji, których celem jest zawarcie omawianego porozumienia zbiorowego. Po drugie zaś, przystąpienie do rokowań

12 Por. L. Florek, Kodeks pracy. Komentarz..., s. 1125. 
i ich prowadzenie bez woli zawarcia układu byłoby działaniem pozornym, a więc w złej wierze ${ }^{13}$.

„Poszanowanie słusznych interesów drugiej strony" oznacza potrzebę uwzględniania interesów nie tyle związków zawodowych lub np. organizacji pracodawców jako strony układu, ile poszanowanie interesów strony pracowniczej, reprezentowanej przez związki zawodowe, oraz interesów strony pracodawczej, reprezentowanej w szczególności przez organizację pracodawców. W wyroku z dnia 22 września 1999 r. ${ }^{14}$ zbiorowy interes pracowników, do którego reprezentowania powołane są związki zawodowe, nie może być utożsamiany z własnym interesem prawnym związku zawodowego. Stosownie do art. $241^{3} \S 1$ k.p. realizacja tej dyrektywy oznacza w szczególności uwzględnianie postulatów związków zawodowych uzasadnionych sytuacją ekonomiczną pracodawcy (pracodawców) oraz powstrzymywanie się od wysuwania postulatów, których realizacja $\mathrm{w}$ sposób oczywisty przekracza możliwości finansowe strony pracodawczej. Dokonując próby przybliżenia tej klauzuli generalnej, ustawodawca posłużył się zwrotami ogólnymi i nieprecyzyjnymi. Po pierwsze, w art. $241^{3} \S 1$ pkt 1 i 2 k.p. użył pojęć bliskoznacznych „sytuacja ekonomiczna” i „możliwości finansowe”. Można oczywiście podejmować próbę ich rozróżnienia, jednakże, uwzględniając ich kontekst znaczeniowy, wydaje się, że użyto ich wymiennie. $W$ art. $241^{3} \S 1$ pkt 1 k.p. nie wskazano, jaka sytuacja ekonomiczna strony pracodawczej ma uzasadniać uwzględnianie postulatów związkowych. Wydaje się, że powinna to być taka kondycja ekonomiczna, która umożliwia spełnienie postulatów związkowych bez uszczerbku dla osiągania celów działalności prowadzonej przez pracodawcę oraz jej perspektyw rozwojowych. Z kolei na tle art. $241^{3} \S 1$ pkt 2 k.p. powstaje pytanie: według jakich kryteriów należy oceniać, czy zgłoszone przez związki zawodowe postulaty przekraczają „w sposób oczywisty” możliwości finansowe pracodawcy (pracodawców). Z punktu widzenia prowadzenia negocjacji w dobrej wierze i z poszanowaniem słusznych interesów drugiej strony wysoce wątpliwe jest wskazanie przez związki zawodowe postulatów, które w sposób oczywisty przekraczają możliwości finansowe strony pracodawczej, a contrario dopuszcza się zgłaszanie postulatów, które przewyższają te możliwości, lecz nie w sposób oczywisty. De lege ferenda wypada zgłosić wniosek rezygnacji z normatywnego egzemplifikowania na czym mają polegać negocjacje układowe $\mathrm{w}$ dobrej wierze i pozostawić interpretację przybliżenie pojęcia "dobra wiara" judykaturze i doktrynie ${ }^{15}$.

\footnotetext{
${ }^{13}$ Por. K. Rączka, Kodeks pracy. Komentarz..., s. 1194.

${ }^{14}$ I PKN 278/99, OSNAPiUS 2001, nr 2, poz. 42.

${ }^{15}$ K. Rączka, Kodeks pracy. Komentarz..., s. 1196.
} 
Artykuł $241^{3} \S 1$ pkt 3 k.p. stanowi, że w ramach negocjacji układowych niezbędne jest poszanowanie interesów pracowników nieobjętych układem. Należy pamiętać, że strony układu mogą wyłączyć z układu określonych pracowników, pewne grupy pracowników nie mogą być objęte regulacją układową z mocy prawa; niektóre zaś mogą być wyłączone z regulacji układowej postanowieniem stron układu zbiorowego pracy (por. art. 239 k.p.). Nieobjęcie określonej grupy pracowników układem nie może oznaczać pomijania w rokowaniach ich interesów. Omawiana wskazówka została potraktowana jako egzemplifikacja prowadzenia rokowań w dobrej wierze i z poszanowaniem słusznych interesów drugiej strony. Tymczasem trudno ją rozpatrywać w tym kontekście. $W$ istocie rzeczy stanowi ona trzecia, równorzędną wobec omówionych, wytyczną do prowadzenia negocjacji.

Ustalając zasady prowadzenia negocjacji układowych, ustawodawca nie przewidział jednak bezpośrednich sankcji za ich naruszenie. Można więc powiedzieć, że prowadzenie rokowań zgodnie z wymaganiami określonymi $w$ art. $241^{3}$ k.p. jest nie tyle obowiązkiem prawnym, ile powinnością prawną. Trafnie się jednak wskazuje, że w związku z naruszeniem omówionych reguł mogą zostać zastosowane pewne środki pośrednie, a mianowicie każda ze stron może $\mathrm{w}$ takiej sytuacji zerwać rokowania, a związki zawodowe mogą także wszcząć spór zbiorowy ${ }^{16}$.

$\mathrm{Z}$ istoty rokowań wynika, że w czasie ich trwania mogą powstawać kwestie sporne. $Z$ reguły przybierają one postać zbiorowych sporów pracy. $W$ celu uniknięcia sięgania $w$ takich sytuacjach do instrumentów przewidzianych w ustawie z 23 maja 1991 r. o rozwiązywaniu sporów zbiorowych ${ }^{17}$, przede wszystkim do strajku, w art. $241^{3} \S 2$ k.p. dopuszczono możliwość ustanowienia na czas negocjacji zasady pokoju społecznego, czyli wyeliminowania konfrontacyjnych metod rozwiązywania sporów zbiorowych. W ramach procedury rozstrzygania sporów powstałych na tle negocjacji układowych strony mogą ustalić np., że spór taki będzie rozstrzygany $\mathrm{w}$ drodze mediacji lub wiążącego strony arbitrażu z wyłączeniem prawa do strajku. Negocjowanie układu zbiorowego pracy pod groźbą strajku może być uznane za brak dobrej wiary.

\section{Prawo do informacji}

Ważnym wyznacznikiem efektywnego przebiegu rokowań dotyczących zawarcia układu jest odpowiednia wiedza ich uczestników na temat sytuacji ekonomicznej i perspektyw rozwojowych pracodawcy (pracodawców) oraz sytuacji socjalno-bytowej pracowników i ich rodzin. W celu

${ }^{16}$ Por. L. Florek, w Kodeks pracy. Komentarz..., s. 1125 i nast.

17 DzU, 1991, nr 55, poz. 236 ze zm. 
umożliwienia uzyskania tej wiedzy ustawodawca nałożył na stronę pracodawczą obowiązek udzielania związkom zawodowym informacji o swojej sytuacji ekonomicznej w zakresie objętym rokowaniami, niezbędnych do prowadzenia odpowiedzialnych negocjacji. Na tle unormowania zawartego $\mathrm{w}$ art. $241^{4} \S 1$ k.p. dotyczącego udostępniania stosownych informacji powstaje pytanie o jego relację do rozwiązania przyjętego $\mathrm{w}$ art. 28 ustawy z dnia 23 maja $1991 \mathrm{r}$. o związkach zawodowych ${ }^{18}$. Prima facie mogłoby się wydawać, że komentowany artykuł stanowi zbędną w istocie egzemplifikację powołanego przepisu ustawy o związkach zawodowych. Jednakże dokładniejsza analiza porównawcza tych przepisów wskazuje, że w $\S 1$ art. $241^{4}$ mamy do czynienia z nowym jakościowo obowiązkiem. Reguluje on bowiem stosunki między pracodawcą i stroną związkową nie tylko na poziomie zakładowym, lecz także i ponadzakładowym, podczas gdy art. 28 ustawy o związkach zawodowych reguluje stosunki między pracodawcą i zakładową organizacją związkową.

Artykuł $241^{4} \S 1$ k.p. stanowi, że związkom zawodowym udostępnia się informacje ograniczone do spraw objętych negocjacjami i niezbędne do prowadzenia rokowań. O ile stosunkowo łatwo można ustalić zakres informacji zdeterminowany przedmiotem negocjacji, o tyle nieprecyzyjne jest sformułowanie, że obowiązek ten obejmuje informacje niezbędne do prowadzenia odpowiedzialnych negocjacji. Sformułowanie to jest tak ogólne i pojemne, że w praktyce może być pretekstem do żądania udzielenia stronie związkowej wszelkich informacji dotyczących kondycji ekonomicznej pracodawcy (pracodawców), niezależnie od obiektywnej potrzeby ich posiadania. De lege ferenda należałoby zrezygnować z tej części unormowania zawartego w powołanym przepisie ${ }^{19}$.

Określając przykładowo rodzaje informacji objętych analizowanym obowiązkiem, ustawodawca wskazał na informacje objęte sprawozdawczością Głównego Urzędu Statystycznego ${ }^{20}$. Poza nimi należy związkom zawodowym przekazać inne dane mające znaczenie dla ustalenia sytuacji ekonomicznej pracodawcy (pracodawców) zarówno w ujęciu statystycznym, jak i analitycznym, obrazujące aktualną sytuację i perspektywy rozwojowe. Chodzi w szczególności o informacje dotyczące zamierzeń inwestycyjnych, kierunków i kosztów modernizacji zakładu pracy itd.

Mimo że ustawodawca starał się nadać obowiązkowi udzielania informacji szeroki zakres, to jednak dokonał pewnego, można domniemywać niezamierzonego, ale istotnego, ograniczenia jego zakresu przedmiotowego. Należy wskazać, że w $\S 1$ art. $241^{4}$ k.p. jest mowa tylko o informacjach dotyczących sytuacji ekonomicznej strony pracodawczej, podczas

18 Tekst jedn. DzU, 2001, nr 79, poz. 854 ze zm.

19 Por. K. Rączka, Kodeks pracy. Komentarz..., s. 1197.

${ }^{20}$ Por. ustawa z 29 czerwca 1995 r. o statystyce publicznej, DzU, nr 88, poz. 439 ze zm. 
gdy zakres informacji, które dotyczą spraw objętych rokowaniami układowymi wykracza znacznie poza charakterystykę sytuacji ekonomicznej. Uwzględniając zakres przedmiotowy układów zbiorowych pracy, łatwo zauważyć, że dla powodzenia rokowań niezbędne mogą okazać się informacje dotyczące spraw organizacyjnych, technicznych lub technologicznych, a także perspektyw rozwojowych czy też sytuacji na branżowym rynku pracy albo rynku produkcji lub usług, na którym funkcjonuje pracodawca. Tymczasem literalna wykładnia $\S 1$ art. $241^{4}$ k.p. wskazuje, że ustanowioną $\mathrm{w}$ nim powinnością informacje te nie zostały objęte. Często jednak $\mathrm{w}$ interesie strony pracodawczej będzie leżeć dobrowolne, z własnej inicjatywy lub inicjatywy związku zawodowego, przekazanie danych dotyczących tych spraw.

Z dostępem przedstawicieli związków zawodowych do informacji wiąże się kwestia ochrony tajemnicy przedsiębiorstwa. Problematykę tej tajemnicy reguluje ustawa z 16 kwietnia 1993 r. o zwalczaniu nieuczciwej konkurencji ${ }^{21}$. Zgodnie $\mathrm{z}$ art. 11 ust. 4 tej ustawy przez tajemnicę przedsiębiorstwa rozumie się nieujawnione do wiadomości publicznej informacje techniczne, technologiczne, organizacyjne przedsiębiorstwa lub inne informacje mające wartość gospodarczą, co do których przedsiębiorca podjął niezbędne działania w celu zachowania ich poufności. Ujawnienie tajemnicy przedsiębiorstwa powoduje odpowiedzialność odszkodowawczą i karna, a w odniesieniu do pracowników przedsiębiorcy może być ono potraktowane także jako ciężkie naruszenie obowiązków pracowniczych, stanowiące podstawę rozwiązania stosunku pracy bez wypowiedzenia $\mathrm{z}$ winy pracownika ${ }^{22}$. Należy zwrócić uwagę na to, że na mocy analizowanego artykułu chronieni są tylko pracodawcy będący przedsiębiorcami, pominięto natomiast pracodawców spoza sfery obrotu gospodarczego, którzy mogą być zobligowani do przekazania przedstawicielom związków zawodowych szczególnie ważnych informacji, których ujawnienie mogłoby narazić pracodawcę na szkodę, czyli informacji, których ranga jest analogiczna do informacji objętych tajemnicą przedsiębiorstwa. O ich równorzędności świadczy choćby art. $101^{2} \S 1$ k.p., który upoważnia do zawarcia umowy o zakazie konkurencji z wszystkimi pracownikami mającymi dostęp do szczególnie ważnych informacji, niezależnie od tego, czy pracują oni u pracodawców będących przedsiębiorcami, czy u pozostałych. Można więc stwierdzić pewną niekonsekwencję prawodawcy bądź niedostrzeżenie istotnego prawnie problemu, która to niekonsekwencja de lege ferenda powinna zostać usunięta.

Stan niezbędnej wiedzy do prowadzenia odpowiedzialnych i efektywnych rokowań układowych wiąże się nie tylko z dostępem ich uczestni-

${ }^{21}$ Tekst jedn. DzU, 2003, nr 153, poz. 1503 ze zm.

${ }^{22}$ Por. art. 52 k.p. 
ków do odpowiednich informacji, ale także z możnością wyjaśnienia wątpliwości, jakie powstają w czasie ich trwania, i zasięgnięcia w tym celu fachowej opinii. W czasie negocjacji może zajść również potrzeba ustalenia rzeczywistego stanu rzeczy i w tym celu niezbędne okaże się opracowanie ekspertyzy. Kwestie te zostały unormowane w art. $241^{4} \S 3$ k.p. Z zawartego w nim unormowania wynika kilka wniosków: po pierwsze, w przypadku wielości uczestników po stronie związkowej lub, wyjątkowo, pracodawczej, żądanie powołania eksperta musi być wynikiem ich wspólnego oświadczenia woli; po drugie, nie można odmówić żądaniu drugiej strony powołania eksperta; po trzecie wreszcie, mimo że inicjatywa ustanowienia eksperta pochodzi od jednej ze stron, na jego osobę powinni wyrazić zgodę wszyscy uczestnicy rokowań, gdyż tylko w takiej sytuacji przygotowana ekspertyza może stanowić wiarygodną podstawę do prowadzenia negocjacji. Oczywiście nic nie stoi na przeszkodzie, aby ekspert został powołany na wspólny wniosek obydwu stron. Niezgadzanie się przez jedną ze stron na powołanie eksperta może doprowadzić do paraliżu rokowań układowych, a nawet do ich zerwania. Koszty ekspertyzy pokrywa strona, która żądała ustanowienia eksperta, chyba że strony postanowiły inaczej. Należy wyjść z założenia, że w przypadku wspólnego stanowiska stron co do potrzeby powołania eksperta koszty sporządzenia opinii powinny obciążać $\mathrm{w}$ równych częściach obydwie strony negocjacji.

Wprawdzie Kodeks pracy nie przewiduje wyraźnie możliwości powoływania przez strony doradców (konsultantów), jednak należy przyjąć, że każdy uczestnik negocjacji w ramach przysługującej mu autonomii i swobody działania może podjać stosowne działania w tym zakresie. W odróżnieniu od ekspertów, którzy powinni działać bezstronnie (obiektywnie), doradcy (konsultanci) działają na rzecz i w interesie strony, która ich ustanowiła. Oczywiście w interesie strony leży to, aby usługi doradcy (konsultanta) były jak najbardziej kompetentne i niepodyktowane doraźnym interesem zleceniodawcy. Przepisy artykułu $241^{4} \S 1-3$ k.p. nie naruszają przepisów ustawy z 2 stycznia 2010 r. o ochronie informacji niejawnych ${ }^{23}$. Podobną regułę należy przyjąć, moim zdaniem, w odniesieniu do ustawy z 29 sierpnia 1997 r. o ochronie danych osobowych ${ }^{24}$. Wprawdzie analizowany artykuł nie odwołuje się do niej, jednakże należy pamiętać, że przetwarzanie tych danych jest możliwe tylko w sytuacjach przewidzianych $\mathrm{w}$ art. 23 powołanej ustawy. Żadna z nich nie jest aktualna w kontekście art. $241^{4}$ k.p. Wprawdzie w art. 23 z 29 sierpnia 1997 r. dopuszcza się przetwarzanie danych osobowych, gdy zezwalają na to przepisy prawa, lecz to ustawowe upoważnienie musi być odpowiednio skonkretyzowane, tymczasem cechy tej nie spełnia $\S 1$ art. $241^{4} \mathrm{k}$.p.

${ }^{23}$ DzU, 2010, nr 182, poz. 1228 ze zm.

${ }^{24}$ Tekst jedn. DzU, 2002, nr 101, poz. 926 ze zm. 


\section{Podsumowanie}

Całościowa analiza kodeksowych przepisów o negocjowaniu układów zbiorowych pracy pozwala stwierdzić, iż w istotny sposób formalizuje ona proces ich podejmowania i prowadzenia zarówno gdy chodzi o dobrowolność ich podejmowania, jak i o zasady prowadzenia, przy czym część unormowań zasługuje na krytykę. W pierwszej kolejności dotyczy ona zasady dobrowolności negocjacji układowych. Mimo że art. 241 $\S 3$ k.p. formalnie statuuje zasadę dobrowolności negocjacji układowych, to jednak zakres i sposób ujęcia sytuacji, w których strona będąca adresatem inicjatywy układowej nie może odmówić żądaniu drugiej strony, powoduja iż de facto mamy do czynienia z obligatoryjnością negocjacji układowych, zwłaszcza gdy z ich inicjatywą występują związki zawodowe. O ile bowiem strona pracodawcza nie ma w zasadzie w stosunku do związków zawodowych instrumentu egzekwującego ich powinność podjęcia i prowadzenia rokowań, o tyle te ostatnie mają taką możliwość; jest nią spór zbiorowy z powołaniem się na naruszenie podstawowej, konstytucyjnej kompetencji związkowej - możliwości negocjacji zbiorowych. Dotyczy to głównie przesłanki zmiany sytuacji ekonomicznej bądź finansowej pracodawców. Przesłanki te zostały określone w sposób nazbyt ogólny i trudno weryfikowalny. Jeżeli przyjąć, że oceny aktualności tych przesłanek dokonuje w sposób autonomiczny każdy podmiot uprawniony do wystąpienia z inicjatywą zawarcia układu zbiorowego pracy, to należy uznać, że ustawodawca dopuścił subiektywizację tych ocen. Okoliczność ta może być czynnikiem konfliktogennym, ponieważ umożliwia odmienność ocen w sprawie tak istotnej, jak konieczność podjęcia rokowań układowych. Sytuacji powstawania sporów na tle istnienia obowiązku rozpoczęcia negocjacji układowych może zapobiec określenie w układzie, który miałby podlegać nowelizacji na podstawie wymienionych przesłanek, trybu i warunków ustalania, czy istotnej zmianie uległa sytuacja ekonomiczna lub finansowa pracodawców oraz czy pogorszeniu uległa sytuacja materialna pracowników. Radykalniejszym rozwiązaniem byłaby rezygnacja z omawianych tu przesłanek obligatoryjności negocjacji układowych.

Negocjacje układowe prowadzone być powinny w dobrej wierze i z poszanowaniem słusznych interesów drugiej strony. Dokonując próby przybliżenia powyższych zwrotów niedookreślonych, ustawodawca posłużył się zwrotami ogólnymi i nieprecyzyjnymi. Po pierwsze, w art. $241^{3}$ $\S 1$ pkt 1 i 2 k.p. użył pojęć bliskoznacznych "sytuacja ekonomiczna" i „możliwości finansowe”. Można oczywiście - o czym była już mowa - podejmować próbę ich rozróżnienia, jednakże, uwzględniając ich kontekst znaczeniowy, uprawnione jest założenie, że użyto ich wymiennie. 
W art. $241^{3} \S 1$ pkt 1 k.p. nie wskazano, jaka sytuacja ekonomiczna strony pracodawczej ma uzasadniać uwzględnianie postulatów związkowych. Wydaje się, iż powinna to być taka kondycja ekonomiczna, która umożliwia spełnienie postulatów związkowych bez uszczerbku dla osiągnięcia celów działalności prowadzonej przez pracodawcę oraz jego perspektyw rozwojowych. $Z$ kolei na tle art. $241^{3} \S 1$ pkt 2 k.p. powstaje pytanie, według jakich kryteriów należy oceniać, czy zgłoszone przez związki zawodowe postulaty przekraczają „w sposób oczywisty” możliwości finansowe pracodawcy (pracodawców). Z punktu widzenia prowadzenia negocjacji w dobrej wierze i z poszanowaniem słusznych interesów drugiej strony wysoce wątpliwe jest bowiem wskazanie przez związki zawodowe postulatów, które w sposób oczywisty przekraczają możliwości finansowe strony pracodawczej, a contrario dopuszcza się zgłaszanie postulatów, które przewyższają te możliwości, lecz nie w sposób oczywisty. De lege ferenda wypada zgłosić wniosek rezygnacji z normatywnego egzemplifikowania, na czym mają polegać negocjacje układowe w dobrej wierze i pozostawić interpretację, przybliżenie pojęcia „dobra wiara” judykaturze i doktrynie.

\section{Bibliografia}

Florek L. (red.), Kodeks pracy. Komentarz, Warszawa 2011.

Gersdorf M., Rączka K., Raczkowski M., Kodeks pracy. Komentarz, Warszawa 2014.

Hajn Z., Status prawny organizacji pracodawców, Warszawa 1999.

Stownik poprawnej polszczyzny, Warszawa 1995.

\section{Negotiations concerning Collective Labour Agreements}

\section{Summary}

Collective bargaining in employment relations is one of the most important instruments for shaping the modern system of employment. An overall analysis of the Labour Code regulations on collective agreements negotiations allows to state it significantly formalizes the process of its commencement and conduct in the scope of voluntariness of their commencement and rules of performance as for their conduct, however some of the legislation should be criticized. Collective agreements negotiations should be conducted in good faith and with due regard for the legitimate interests of the other party. From the point of view of the conduct of collective agreements negotiations in good faith and with due regard for the legitimate interests of the other party an indication established as a result of the demands of the trade unions, which clearly exceed the financial capabilities of the parties of the workers' side, is doubtful, a contrario it shall be permitted to submit demands, which exceed these capabilities, but so far it is not clear. De lege ferenda is to request of resignation from the normative exemplification, what collective agreements negotiations in good faith are and leave the interpretation of the concept of "good faith" to judicature and doctrine. 